\title{
Dekonstruksi Bomoh Dalam Ritual Bedekeh Suku Akit di Rupat Bengkalis Provinsi Riau
}

\author{
${ }^{1}$ Suroyo, ${ }^{2}$ Fatmahwati A \\ ${ }^{1}$ Pendidikan Sejarah FKIP Universitas Riau \\ Suroyokajian123@gmail.com \\ ${ }^{2}$ Balai Bahasa Provinsi Riau \\ fatmaadnan@yahoo.com
}

\begin{abstract}
Bedekeh is medical traditional treatment that is from the ancient treatment of ancestor that has been done by Akit People when they need treatment such as seek and seen the desease or illness from the body of someone. This ritual is contained mystics which they believe if there is relation with the curing that is helped by the spirit of ancestor Akit that is based of Akit people's faith. Both Batin and Bomoh have a big role of Akit Tribes life cycles. The role of Batin in Akit Tribe is important because they not only keep the tradition culture of Akit exist, but also lead the Bedekeh ritual (as Bomoh Besar). Nowadays, exsistent of Batin is not used by or important because Batin himself has been replaced by the Village Head of Hutan Panjang (Kepala Desa) that is not nesessary from Akit People. When there was Undang-Undang Desa (Village Laws), Batin had two roles, Kepala Desa (Village Head) and the leader of Bedekeh Ritual. In Akit People, Batin and Bomoh have certain social roles and cultural system of Akit. The Profession of Bomoh politically authoritative discourse of power. The Position of Bomoh attract the variety of interests as the legitimacy of power. That posistion is used to gain the position, respect, and power. Discourse of power or knowledge is Foucault's Theory, about correlation between Discourse, power, and knowledge to become the aspect in power of Batin and Bomoh for Bedekeh ritual for Akit People.
\end{abstract}

Keywords: dekonstruksi, bomoh, bedekeh, Akit

\section{PENDAhULUAN}

Suku Akit dan masyarakat pendukungnya telah memiliki pengetahuan lokal (local knowlegde) dan kearifan lokal (local wisdom) dalam mengatasi berbagai masalah dalam komunitasnya, terutama masalah kesehatan dan cara mengobatinya apabila masyarakat mengalami gangguan kesehatan. Hal-hal yang terkait dengan tradisi lisan dapat diaktualisasikan ke dalam sastra dan seni pertunjukan, religi dan upacara, pengetahuan tradisional serta sistem kognitif lainnya, manusia dan lingkungannya, dan sebagainya (Pedoman KTL, 2009: 15--27).

Bedekeh merupakan tradisi ritual pengobatan yang bersumber dari ajaran leluhur dan hal itu dilaksanakan ketika masyarakat Akit sedang membutuhkan jasa pengobatan yang merupakan mencari atau melihat suatu penyakit pada diri seseorang. Ritual ini mengandung berbagai unsur mistis, bahkan mereka meyakini adanya kaitan penyembuhan yang dilakukan langsung oleh jin-jin atau roh leluhur tertentu, sesuai dengan pengetahuan dan keyakinan masyarakat. (Suroyo: 2017: 2). Foster dan Anderson (1986: 63) yang telah melakukan penelitian sebelumnya di tempat yang lain menyatakan bahwa sakit disebabkan oleh adanya agen (perantara), baik berupa makluk supranatural (makluk gaib atau dewa), makluk bukan manusia (hantu, roh leluhur atau roh jahat), maupun makluk manusia (tukang sihir atau tenung).

Suku Akit dan masyarakat pendukungnya telah memiliki pengetahuan lokal (local knowlegde) dan kearifan lokal (local wisdom) dalam mengatasi berbagai masalah dalam komunitasnya, terutama masalah kesehatan dan cara mengobatinya apabila masyarakat mengalami gangguan kesehatan. Hal-hal yang terkait dengan tradisi lisan dapat diaktualisasikan ke dalam sastra dan seni pertunjukan, religi dan upacara, pengetahuan tradisional serta sistem kognitif lainnya, manusia dan lingkungannya, dan sebagainya (Pedoman KTL, 2009: 15--27). Giddens (2003: 48--50) mengemukakan tradisi merupakan adat atau kebiasaan (custom or habit), yang merupakan penanda identitas baik secara pribadi maupun kolektif masyarakat pendukungnya. Identitas adalah penciptaan konstansi dalam perjalanan waktu, yang 
menghubungkan masa lalu dengan masa depan masyarakat pewarisnya dengan realitas identitas sosial yang lebih luas, dalam hal ini disebut dengan perhatian psikologis.

Ritual bedekeh dipimpin langsung oleh pemimpin suku Akit (batin) dengan dibantu oleh bomoh kecik (kecil), bomoh menengah, dan bomoh besar (batin) serta penabuh gendang (pebayun) untuk mengetahui penyebab serta mengobati penyakit pada suku Akit.

Foucault (1977:27--28) dalam The Archaelogy of Knowledge, mengatakan Kekuasaan menciptakan pengetahuan...Kekuasaan dang pengetahuan saling menghasilkan... Tidak ada kekuasaan tanpa hubungan dengan kekuasan. Hubungan "kekuasaan pengetahuan" ini harus diteliti...bukan berdasarkan seorang peneliti yang bebas atau tidak dari kekuasaan. Sebaliknya, subjek yang mengetahui, objek yang diketahui, dan bahan-bahan pengetahuan harus dipandang sebagai dampak implikasi dari hubungan kekuasaan pengathuan dan perubahan-perubahannya dalam sejarah. Singkatnya, bukanlah tindakan subjek yang menghasilkan pengetahuan, tetapi kekuasaanpengetahuan proses dan pergualatan yang memwarnainya dan menciptakannya dengan menentukan bentuk dan bidang pengetahuan yang mungkin.

Mengacu pada pendapat tersebut, pertanyaan penelitian yang diajukan dalam kajian ini adalah bagaimana dekonstruksi bomoh dalam ritual bedekeh? Bagaimanakah relasi kuasa dan pengetahuan bomoh dengan kehidupan sosial budaya suku Akit? Seiring dengan pertanyaan penelitian tersebut, kajian ini bertujuan untuk memaparkan dekonstruksi bomoh dalam ritual bedekeh dan menjelaskan keterkaitannya dengan kehidupan sosial budaya suku Akit.

\section{METODE}

Karena penelitian ini merupakan sebuah penelitian kajian budaya (cultural studies), maka penelitian ini mengintegrasikan disiplin-disiplin lain. Hal ini sesuai dengan prinsip lintas bidang atau multidisiplin dalam kajian budaya, seperti semangat tiadanya batas dalam ilmu sosial. Di samping itu, kajian ini bersifat multidisiplinner dengan adanya berbagai fenomena menarik di dalamnya, seperti pariwisata, politik historis, sosial budaya, lingkungan, arkeologi, dan sebagainya. Sebagai kajian budaya, penelitian ini dirancang dengan pendekatan kualitatif. Kajian budaya menggunakan metode yang menekankan keterkaitan budaya dengan masalah sosial dan kehidupan sehari-hari. Cultural studies mencoba mendekonstruksi pandangan lama dan mengangkat budaya yang terpinggirkan pada tingkat yang wajar. Bertitik tolak dari penjelasan tersebut dan mengingat ritual pengobatan suku Akit yang semakin terpinggirkan oleh arus globalisasi merupakan kajian budaya, maka teori wacana kuasa dan pengetahuan, dari Foucoult untuk menganalisis data. Penggunaan teori tersebut dipandang relevan untuk memahami dekonstruksi kuasa dan pengetahuan ritual bedekeh oleh Bomoh pada suku Akit di Rupat Kabupaten Bengkalis, Provinsi Riau. Bagi Foucault jika ingin mengetahui mengapa wacana tertentu begitu berkuasa, yaitu menelususri asal usul cara mengetahui dengan melakukan dekonstruksi dan meneliti landasan yang padanya kekuasaan itu berbeda dan dominan. Bagi Foucault, diskursus adalah kerangka kerja yang ditentukan oleh yang berkuasa yang ditetapkan melalui hubungan-hubungan kekuasaan yang mendasarinya. (Fakih, 1997: 169). Dengan demikian, setiap diskursus tentang kebudayaan tidak terlepas dari kepentingan dan kekuasaan.

\section{HASIL DAN PEMBAHASAN}

Hasil penelitian ini disajikan secara naratif sesuai dengan penelitian kajian budaya yang menggunakan metode kualitatif terkait dengan topik bahasan. Penelitian ritual bedekeh pada suku Akit yang dirancang sesuai dengan paradigma keilmuan kajian budaya (cultural studies). Berdasarkan data di lapangan diketahui bahwa ritual pengobatan yang dilaksanakan dalam upacara tersebut sebelum upacara ritual pengobatan dilaksanakan, ada beberapa persyaratan dan ketentuan yang harus dipersiapkan. Untuk lebih jelasnya persyaratan dan proses ritual yang harus dilakukan dapat dilihat di bawah ini.

Berdasarkan data di lapangan diketahui bahwa terlebih dahulu seorang batin menentukan tempat dan waktu yang terbaik dalam melaksanakan upacara ritual ini dan mempersiapkan sesaji yang dipersembahkan untuk dewa-dewa leluhur yang akan dipanggil sebagai penolong dalam ritual tersebut. Inilah fungsi batin atau kepala suku bagaimana menempatkan diri 
untuk berdiskusi bersama masyarakat pendukungnya. Pelaksanaan upacara ritual ini disesuaikan dengan upacara yang dilakukan. Jika untuk mengobati orang sakit, maka dapat dilakukan di dalam rumah, boleh juga dilakukan di halaman rumah. Hal ini disesuaikan dengan permintaan dewa melalui perantara batin.

Pelaku pengobatan ataupun ritual pengobatan sangat bertanggung jawab dalam melaksanakannya. Pelaku pengobatan, meliputi batin, bomoh, antan, jokrah dan pebayu. Orangorang yang terpilih sebagai pendukung pelaksanaan ritual ini adalah batin. Selama proses pengobatan berlangsung pebayu berperan penting membantu bomoh dalam mengambil apa-apa yang diminta oleh bomoh. Pebayu bekerja menghias rumah-rumahan (bale) dengan menyusun atau menggantungkan perlengkapan pengobatan ritual seperti motif-motif binatang yang terbuat dari daun kopau dan daun nyiur dan memasang lilin lebah. Pebayu tersebut bisa dari pihak keluarga, asalkan mengerti tentang atau cara dalam ritual bedekeh. Pebayu bisa dilakukan oleh siapa saja, baik perempuan maupun laki-laki tetapi sudah balig. Pebayu bisa dilakukan beberapa orang, yaitu dua atau tiga, mengingat banyaknya perlengkapan yang harus dipasang pada rumah-rumahan, lancang, anyaman, dan lainnya. Istri bomoh juga berperan penting dalam melakukan persiapan segala perlengkapan atau persyaratan yang akan digunakan pada saat pengobatan.

Berdasarkan data di lapangan diketahui bahwa sebelum upacara ritual pengobatan dilaksanakan, ada beberapa persyaratan dan ketentuan yang harus dipersiapkan. Sebelum pelaksanaan upacara ritual pengobatan masyarakat Akit mencari dan mempersiapkan segala sesuatu keperluan untuk upacara pengobatan tersebut. Masyarakat Akit diberikan kewajiban membawa beras, kelapa, ayam untuk bekal orang banyak yang ikut dalam pelaksanaan ritual pengobatan tersebut. Kemudian rumah tempat upacara pengobatan betul-betul dipersiapkan dengan matang.

Prosedur dalam ritual yang dilakukan oleh bomoh Akit dibagi ke dalam enam peringkat berikut.

(1) Membuat ramuan obat-obatan (medicine)

(2) Memberikan doa berupa pembacan mantra

(3) Diagnosis

(4) Persembahan-persembahan

(5) Berkelana atau berkomunikasi dengan roh dewa

(6) Mengembalikan jiwa pada pasien
Bomoh akan membuat obat-obatan sebagai prosedur pertama dari ritual dan akan mencoba masuk ke jiwa pasien untuk memanggil arwah sebelum ia berkelana ataupun jatuh ke dalam dunia lain. Bomoh mengucapkan mantra dengan membawa air suci dalam tabung dari mata air langsung dan menambahkan bertih dan memasukkan lilin yang berasal dari lebah tawon ke dalamnya. Kadang-kadang beberapa daun sirih juga dimasukkan ke tabung tersebut. Pasien akan meminum segelas air dari tabung tersebut setelah ritual. Selebihnya air yang diminum digunakan untuk mandi pasien pada pagi harinya. Ramuan air tersebut dijadikan obat oleh bomoh terhadap pasien yang diyakini efektif untuk memurnikan tubuh pasien. Kadang-kadang, bomoh akan menempelkan tepung putih (tepong tawar) yang telah dibacakan mantra pada tubuh pasien.

Pembacaan mantra terhadap diri pasien adalah bagian yang penting dari ritual pengobatan supaya pasien sembuh. Bomoh akan berkali-kali mengembuskan mantra ke udara dan mengembuskan mantra ke tubuh pasien. Mantra ini dianggap memberikan tenaga dalam dan kekuatan untuk pasien. Selain itu mantra juga untuk memperkuat tubuh pasien terhadap roh-roh jahat. Selama proses dalam memberikan mantra pada pada tubuh pasien maka dengan hati-hati bomoh akan membisikkan pasien melalui mantra pada bagian atas kepala, jempol kiri dan kanan, dan kedua jari kaki pasien.

Hal ini bertujuan untuk memutuskan hubungan jiwa pasien yang sakit akibat gangguan roh-roh jahat. Beberapa informan yang ditanyai mengatakan bahwa hal tersebut seperti napas Tuhan menciptakan manusia pertama dalam mitologi Akit, bomoh memberikan nyawa (menapas) untuk pasien. Setelah memberikan napas berupa mantra maka bomoh akan mendiagnosis dan akan terbang ataupun mengalami trance pada dunia lain tanpa sadar diri dan tidak diketahui ataupun dibaca oleh orang yang hadir.

Tujuan utama diagnosis ini adalah menentukan jenis atau gangguan pada korban dan apa yang akan dilakukan bomoh dalam ritual berikutnya setelah membaca mantra. Hal pertama yang dilakukan bomoh adalah memandang lampu lilin yang telah dipegang dengan tangan kanan kemudian membuka kipas yang berada pada tangan kirinya sambil berjalan-jalan di sekitar pasien untuk mencari sesuatu. Sambil berjalan di sekitar pasien bomoh sambil mengibas-ngibas kipas dan 
memegang lilin yang berasal dari lebah tawon. Akhirnya, bomoh berhenti sejenak dan terus mencari jiwa pasien dari gangguan roh-roh jahat. Menurut penjelasan masyarakat setempat saat penulis bertanya pada orang yang hadir dalam ritual tersebut, bomoh mencoba untuk mencari jiwa pasien dari gangguan roh-roh jahat yang telah mengganggu pasien menjadi sakit. Bomoh sudah dalam keadaan di luar kesadaran akan dibantu atau dimasuki oleh roh-roh lain dan berkomunikasi dengan roh tersebut.

Roh-roh jahat yang diyakini dapat dilihat melalui kipas yang sedang dikibas-kibaskan dengan simbol warna yang ada di kipas tersebut. Warna kipas tersebut, yaitu berupa warna kotak merah atau kuning yang berjajar di lipatan kipas tersebut. Warna merah berarti roh-roh jahat yang hidup di tanah dan kuning adalah roh jahat yang hidup di laut. Selain dengan simbol warna kadangkadang bomoh menggunakan telinga untuk mendengarkan suara-suara arwah atau roh, menggunakan jarinya untuk menunjuk dan kadang menggunakan kepala untuk mengangguk-angguk dalam berkomunikasi dengan roh tersebut. Dalam ritual ini akan disertai dengan bunyi gendang dan bomoh terbawa oleh suasana magis sehingga pukulan gendang juga semakin kuat. Setelah gendang berhenti sejenak roh-roh dan arwah akan berkomunikasi dengan bomoh. Bomoh pun berbicara berubah-ubah sesuai dengan karakter roh yang sedang ada dalam diri bomoh.

Berdasarkan diagnosis pada malam pertama, akan dilakukan persembahan pada ritual selanjutnya. Peralatan lain yang harus disediakan atau disiapkan, seperti bale (rumah-rumahan), lancang atau (perahu-perahuan), dan makanan, seperti sayuran dan bumbu rempah lainnya, pisang, rokok, bertih (beras kering), air cucian beras, beras kuning, telur, sirih kacang-kacangan, dan lainnya. Makanan ini diletakkan pada beberapa baki. Selama ritual yang dilakukan oleh bomoh. Semua perlengkapan tersebut diletakkan di samping pasien.

Bale dan lancang ini jika sudah selesai ritual, akan dibawa ke hutan dan ke laut sebagai persembahan pada roh laut dan hutan. Bomoh akan berusaha untuk mencari roh-roh jahat dari tubuh pasien. Bomoh akan berusaha mengeluarkan benda ataupun roh jahat yang ada dalam tubuh pasien. Metode ini dalam masyarakat Akit disebut dengan nyabut (mencabut benda). Setelah mencabut benda dan roh jahat pasien maka bomoh memuntahkan dengan cara meludahkan ke dalam air basin. Air ini dibuang ke dalam laut setelah ritual berlangsung. Kadang-kadang, bomoh dapat menemukan sebuah benda seperti paku, kacang, atau serangga dalam mulut. Bomoh berkata bahwa mereka adalah sumber dari dewa kuasa rohani.

Untuk menangkal roh-roh jahat biasanya dilakukan apabila pasien belum mengalami sakit, yaitu dengan cara meletakkan benda atau sesuatu di depan rumah pasien atau seseorang. Benda tersebut biasanya sudah diberikan mantra oleh bomoh untuk menjaga diri dari serangan roh-roh yang berbuat jahat pada seseorang. Akan tetapi kebanyakan orang tidak mengerti kapan akan diserang atau diganggu oleh roh jahat. Bomoh akan menangkap roh-roh jahat langsung dengan tangannya selama ritual. Hal ini dapat dilihat dari bomoh yang tibatiba berubah melakukan gerakan seperti tarian silat atau menari dengan lincah dan sambil memukul dan mendekat pada rumah-rumahan atau bale selama ritual yang dilakukan. Bomoh akan melakukan gerakan menari, melompat, dan kadang-kadang menjatuhkan badannya dan kembali berdiri serta memukul bale dan kelihatan menangkap sesuatu dan menahannya dalam genggaman tangannya.

Setelah dalam genggaman objek yang telah didapatkan oleh bomoh langkah selanjutnya, yaitu akan dimasukkan ke kotak dan dibungkus dengan kain. Ada yang langsung selesai setelah menangkap benda tersebut, tetapi ada yang dibuang jauh ke laut lepas. Hal ini dilakukan apabila rohroh jahat tersebut dianggap sebagai dewa roh atau roh. Objek yang ditangkap oleh bomoh tersebut dengan hati-hati dibungkus dengan baju dan dibuang jauh ke dalam laut. Teknik ini hanya digunakan ketika roh-roh jahat dianggap menjadi sangat jahat dan berbahaya pada penduduk Akit. Selain dengan metode menangkap dan membungkus roh-roh jahat tersebut, bomoh juga bisa menggunakan pisau atau kipas yang sering dikibas-kibaskan saat bomoh menari di luar kesadarannya.

Jika bomoh mengatakan bahwa penyakit pasien ini disebabkan oleh kehilangan jiwa pasien, maka metode ini diterapkan dalam mengembalikan jiwa pasien. Jika bomoh berhasil menemukan jiwa melalui ritual pada komunikasi roh-roh yang berasal dari dari tanah atau laut, bomoh meminta bantuannya untuk kembali pada tempatnya. Rohroh akan membawa jiwa pasien kembali ke tangan bomoh kemudian meniupkan jiwa tersebut pada pasien atau dimasukkan dalam bantal yang 
digunakan oleh pasien agar pasien bias menggunakan jiwa itu kembali pada saat tidur.

Apabila bomoh belum berhasil menemukan jiwa pasien yang pergi, dia pergi ke dunia yang lebih rendah dan mencari jiwa pergi. Untuk hal ini bomoh melakukan perjalanan ritualnya semakin mendalam seperti orang mati, tertanam dalam bumi. Bomoh dalam ritualnya menutup selembar kain pada kepalanya dan menutupi pasiennya juga dengan selembar kain besar seperti halnya seorang mayat yang terbujur ditutupi kain kafan. Pasien tersebut dikelilingi dengan banyak perlengkapan persembahan bagi roh-roh jahat yang hidup di dunia yang lebih rendah.

Biasanya setelah beberapa menit, bomoh mengalami kejang-kejang, kerasukan, dan mengalami kejadian di luar kesadarannya dengan melakukan gerakan berdiri, berjalan, dan melakukan gerakan-gerakan tarian untuk menangkap jiwa pasien yang sedang diobatinya. Kemudian, bomoh mengembalikan jiwa pada pasien. Hal ini dinamakan dengan nyelembah. Biasanya bomoh berhasil dalam mengembalikan jiwa pasien, tetapi kadang-kadang gagal melakukannya. Dalam kasus-kasus yang gagal disebabkan jiwa pasien diambil oleh roh-roh orang yang sudah mati. Roh orang mati mempunyai kekuatan supranatural yang sangat kuat dan diyakini oleh bomoh bahwa jiwa pasien tidak bisa kembali lagi. Bomoh akan mengambil simpulan bahwa jiwanya akan senang berada di tempat itu sebagai tempat persinggahan karena sudah bernegosiasi dengan roh orang mati sehingga bomoh akan berusaha untuk mencari jiwa pasien tersebut.

Menurut pengamatan peneliti, bomoh yang pergi ke dunia lebih rendah bila roh (hantu tetau) tidak menjaga pasien dari roh-roh jahat dengan benar. Walaupun bomoh sudah berusaha memberikan persembahan kepada roh agar roh tersebut dengan apa yang telah dipersembahkan berupa sesajen. Bomoh berusaha pergi ke dunia yang lebih rendah dengan ritual dan mencoba berkomunikasi dengan seorang imam yang lama mati (pawang ladang) apa jenis persembahanpersembahan yang harus disajikan untuk memuaskan roh-roh penjaga bumi. Kemudian, bomoh berusaha memberikan persembahan yang sesuai akhirnya roh yang masuk dalam tubuh bomoh menjadi tenang. Prosedur penyembuhan seperti ini jarang terjadi. Hal ini menggambarkan bahwa bomoh Akit bisa berperan sebagai mediator antara manusia dan orang-orang mati serta antara manusia dan roh-roh.

Upacara ritual biasanya dilakukan oleh satu bomoh, yaitu bomoh besar (batin) dibantu oleh seorang satu asisten kepala (pebayu) dan sedikitnya satu pemain drum (bidung). Ketika bomoh mengatakan bahwa pasien perlu penanganan khusus maka bomoh akan memanggil para pembantu dalam ritual tersebut. Dalam ritual ini hanya bomoh yang bermain peran dan mengendalikan ritual tersebut dan berusaha untuk dapat mengusir roh-roh jahat dari tubuh pasien atau untuk mendapatkan kembali jiwa pasien

Pemain drum memainkan peranan dalam irama cepat dan lambat diiringi dengan gerak kaki bomoh yang sedang malakukan gerakan sesuai dengan tarian yang dilakukan. Sementara asisten bomoh (pebayu) akan sangat hati-hati memperhatikan bomoh dan gerak gerik bomoh agar tidak terbakar api yang ada di depannya. Karena sering kali bomoh di luar kendali dirinya akan melakukan apa saja gerakan apabila sudah berkomunikasi dengan roh-roh dari dunia lain. Kadang-kadang bomoh akan berkeliling di antara api yang ada seperti mencari sesuatu. Suasana seperti ini akan membuat penonton semakin tegang dan terbawa oleh situasi magis yang langsung di depan mata. Walaupun beberapa pasien kadangkadang menangis, berteriak, atau tegang pada tahap ini, tetapi semua akan merasa tenang jika bomoh sudah berhenti dari gerakan-gerakan yang aneh.

Tahapan proses di atas menunjukkan ritus transformasi praktik bomoh menuju tahapan transenden merepresentasikan kesatuan total. Di pihak lain bomoh Akit lebih memanfaatkan ketegangan ini agar pasien tidak beraksi dengan kata-kata atau teriakan mantra. Kata-kata ini kurang penting dalam Akit. Pelaksanaan upacara ritual mempunyai tahap-tahap yang diharus dilakukan. Adapun tahap-tahap yang dilakukan adalah sebagai berikut.

Pertama, bomoh duduk bersila menghadap peralatan upacara ritual lengkap dengan sesajen. Asisten laki laki dan perempuan mengasapi bomoh dengan bakaran kemenyan mulai dari ujung kaki sampai ke ujung kepala atau ubun-ubun, mengasapi seluruh pakaian dari bomoh, dan mengasapi darah ayam dan ayam persembahan. Peralatan dan semua alat alat diasapi dengan asap kemenyan yang dibakar dengan penuh magis dan kehati-hatian.

Kedua, asisten mengambil bahan-bahan untuk mengolesi wajah bomoh dengan ramuan yang terbuat dari kapur sirih. Leher, bahu, dada, 
sampai kaki pada bomoh diolesi dengan kapur sirih. Bomoh akan konsentrasi dengan didampingi para asisten laki-laki dan perempuan. Asisten yang lain segera menabuh gendang dengan alunan perlahanlahan. Semua peralatan yang dipakai dalam acara ritual harus lengkap dan tidak kurang satu pun. Bomoh akan berputar didampingi asisten mengelilingi semua peralatan yang ada dengan tetap diiringi tabuhan musik gendang. Tujuan melihat semua peralatan ini adalah bermaksud bahwa segala alat dan sajian dalam upacara ritual ini dilihat atau dikenal oleh para roh-roh leluhur, para malaikat, dan dewa-dewa yang akan membantunya. Makna dalam mengamati peralatan adalah kesetiaan masyarakat Akit terhadap pada roh leluhur, sedangkan barang atau alat yang dipakai dalam ritual disebut sebagai tanda pengenal bagi roh-roh halus dan malaikat.

Ketiga, yaitu melepas baju yang dipakai bomoh diganti dengan pakaian khusus dalam ritual pengobatan. Pakaian pengobatan itu dipakai hanya pada saat acara ritual pengobatan berlangsung. Pakaian tersebut sebelumnya telah diasapi dengan bakaran kemenyan. Bomoh dipasangi gelang kerincing yang berbentuk bulat dengan banyak bulatan yang di dalamnya bersisi semacam biji sehingga jika digerakkan sedikit saja maka akan berbunyi. Selain dipakaikan gelang pada kaki bomoh yang khusus diberikan saat ritual pengobatan.

Keempat, memasang daun-daunan (kelulusan). Kelulusan terbuat dari daun kelapa muda, daun-daun muda, atau berbagai daun yang masih muda. Bentuk kelulusan itu adalah seperti ditempelkan di kepala, bahu, dada oleh bomoh. Kelulusan ini disebut suku Akit sebagai pakaian para malaikat.

Kelima, menawar bomoh dengan cara mengasapi kembali ibu jari kakinya, kemudian tangan dan jari-jarinya, mengasapi muka dan seluruh tubuhnya dengan asap kemenyan. Selanjutnya meminyaki rambut dan badannya dengan asam kemenyan juga, begitu juga gelang digosokkan ke tubuh bomoh. Seluruh alat dan bahan yang dipakai dalam upacara ritual tersebut terlebih dahulu ditaburi dengan bertih (beras).

Keenam, menghadap membangunkan adalah mengupayakan agar seluruh yang dihadapi atau yang diminta keikutsertaannya dalam pengobatan atau ritual siap untuk bekerja. Acara menghadap ini cukup unik dan agak memakan waktu karena seluruh roh halus dan malaikat serta barang atau alat dipersembahkan pada roh tersebut supaya ikut menyukseskan upacara ritual tersebut. Tahap menghadap diawali dengan mengambil seekor ayam jantan yang sebelumnya telah disiapkan. Ayam jantan ini disebut sebagai ayam bersimbah. Ayam dihadapkan kepada bomoh dan diberikan beras. Apabila ayam tersebut mematok beras itu berarti guru telah menerima ritual ditegakkan dan mulai dilaksanakan ritual. Bomoh mulai memanggil dan kemudian mengajak segala yang dibutuhkan untuk ritual bedekeh. Dalam tahap ritual ini bomoh dan para asisten dalam upacara ritual melakukan gerakan.

Berdasarkan data di lapangan diketahui bahwa sebelum melakukan proses ritual seorang bomoh harus mengetahui jenis penyakit dengan melakukan tilik atau meramal. Selama bomoh dirasuki oleh roh leluhur maka bomoh tersebut mengalami trance (di luar kendali), tingkah laku gerak-gerik, suara, dan sebagainya mengalami perubahan atau terjadi trance.

Bomoh akan menari, bernyanyi, mencari obat, dan sebagainya tidak lagi sebagai pribadi manusia biasa, tetapi sudah menyatu dengan penguasa alam. Dalam tahap ini bomoh telah menyatu antara alam lahir dan alam halus. Bomoh mengatakan bahwa saat inilah alam besar diperkecil, sedangkan alam kecil dihabisi tinggal alam dalam dirinya. Walaupun saat itu orang-orang yang hadir, asisten atau bomoh lain melihat bomoh menari dan menyanyi hakikatnya perilaku bomoh tersebut adalah sedang malakukan perjalanan dan begitu kuatnya untuk dapat menemui makhlukmakhluk halus dengan menyampaikan pujianpujian dan permintaan yang akan disampaikan. Dalam hal ini meminta obat sebagai penawar penyembuhan bagi si pasien kepada dewa, dengan memakai alat penerang, yaitu lilin yang terbuat dari liur binatang lebah, atau lilin biasa yang dipakai sehari-hari untuk alat cahaya atau penerangan penunjuk jalan oleh api.

Bomoh mengalami kemasukan atau sudah dirasuki oleh roh-roh halus. Bomoh dapat berbicara langsung dengan makhluk-makhluk atau roh-roh, Jin dan malaikat-malaikat. Pada saat kerasukan tersebut bomoh meminta obat bagi orang-orang yang datang berobat pada saat itu. Selain mengobati, bomoh juga membuang bala atau sial. Upaya membuat jimat, membuang pantangan, membuang sumbang, membuang sial, dan sebagainya. Sementara bomoh mengobati maka tukang gendang terus-menerus membunyikan gendang dan tidak henti-hentinya. Apa pun bahasa yang diucapkan bomoh pada saat kerasukan tidak 
dimengerti oleh orang yang hadir. Untuk itu diperlukan peranan asisten baik laki-laki maupun perempuan untuk menerjemahkannya. Ramuan obat yang telah ditentukan bomoh boleh juga dicari oleh keluarga yang sakit. Apabila nama ramuan itu tidak dikenal oleh warga, maka tanggung jawab untuk mencarikannya adalah asisten bomoh, baik laki laki maupun perempuan.

Ciri-ciri trance yang terjadi pada bomoh saat pencarian obat antara lain gerak yang dibawakan tak terkendali secara khas. Artinya, makin lama makin cepat kadang lambat, kadang tanpa terkendali memerlukan beberapa gerakan di luar kesadaran dari pengobatan itu sendiri dan semakin lama semakin melambat kadang cepat dan kadang berhenti, dan kembali lagi bergerak secara cepat dan mata memerah serta ada perubahan suara. Perubahan ini terjadi dari permintaan dewa melalui si bomoh, umpamanya permintaan lilin yang disebut jarum halus, minyak wangi yang disebut cantik manis, kemenyan yang disebut asok atau asap kemenyan, gendang yang disebut senandong, dan kain selendang yang disebut kain cinde.

Berhasil atau tidaknya bomoh memperoleh permintaannya kepada dewa, roh halus, atau malaikat dinyatakan setelah sembuh dari kesadarannya. Setelah sadar maka bomoh tersebut lebih lemah dan tak berdaya melakukan aktivitasnya. Jika diamati secara mendalam, saat bomoh kerasukan, tampaknya roh-roh halus, jin, dan malaikat-malaikat berganti-ganti memasuki bomoh. Setiap yang datang itu mempunyai tingkah laku sendiri-sendiri. Hal ini menunjukkan bahwa perilaku bomoh selalu berubah-ubah. Pengobatan dimulai dengan meracik limau (jeruk nipis). Untuk hal pengobatan pun banyak macamnya ada yang hanya memberikan ramuan, dimantrai saja, diberikan jimat, pelindung badan, penunduk ataupun pemanis (laris manis).

Bomoh dalam hal komunikasi dengan roh halus kadang dengan cara meringis, menjilat, diurut, digigit, dan diisap. Ada pula dengan suara keras seperti membentak dan sering marah atau meniru atau menggunakan air liur. Liur dan percikan dengan pinang yang sudah dikunyah halus-halus dan langsung disemprotkan dengan pasien. Bomoh di luar kendali, melakukan apa saja atas perintah dari makhluk-makhluk atau roh-roh halus yang telah merasukinya. Pengobatan yang dilakukan menggunakan perlambangan, yaitu membuang sial, membuang sumbang, membuang pantang, menawar kampung, dan mengusir binatang buas. Pengobatan yang dilakukan menggunakan perlambangan dan hal ini dianggap sakral sekali karena bomoh tersebut di luar kendali pribadinya. Berhasil atau tidaknya bomoh memperoleh permintaannya kepada dewa ataupun roh-roh halus dinyatakan setelah sadar. Setelah sadar maka kelihatan letih, lemah, dan tak berdaya setelah melakukan ritual tersebut.

Hal tersebut menurut Levie Straus (1997: 158) dalam buku Mitos, Dukun dan Sihir keadaan yang dialami seorang individu pada saat ia kehilangan kesadaran, dan mengalami keadaan kayal, yang disebabkan oleh faktor-faktor tertentu. Keadaan ini merupakan keadaan disoasi psikis yang ditandai oleh kurangnya gerakan yang dilakukan secara sengaja dan sering ditandai oleh terjadinya automatisme dalam tindakan dan pikiran. Keadaan tidak sadarkan diri sering dicontohkan dalam keadaan hipnotis dan medium mistik atau keadaan pribadi berfungsi sebagai medium kabar roh-roh. Aktivitas pengobatan dapat dilakukan setelah bomoh mengetahui jenis penyakit yang diderita oleh si sakit serta kebutuhan-kebutuhan yang diperlukan untuk upacara ritual pengobatan yang harus dipersiapkan.

Komunikasi yang fundamental sebagai dialog bomoh dengan roh hanya dimengerti oleh bomoh itu sendiri. Di pihak lain upacara ritual pengobatan tidak bisa memulai ritual pemanggilan roh jika musik belum dimainkan atau bomoh meminta musik untuk mulai memainkan musiknya. Apabila roh sudah menyatu atau roh sudah keluar lagi, bomoh mulai memberikan isyarat kepada pemusik untuk menghentikan.

Bomoh duduk dengan memejamkan mata sambil membaca mantra. Mantra dibacakan dengan suara yang agak keras. Pada saat membacakan mantra bomoh harus menutupi kepalanya dengan kain tudung. Ketika bomoh sudah siap dengan perlengkapannya, kemudian mulai melaksanakan kegiatan ritual dengan syarat yang sudah dipersiapkan, antara lain daun kopau atau daun nipah, nyiur, mayang pinang, bertih atau beras yang digongseng, beras kunyit, tepung tawar, sirih, kemenyan, ayam jantan, kayu atau yang masih muda. Pasu atau tempat air seperti mangkuk pisau, cupak atau tempurung kelapa, tikar pandan, lilin lebah, pasu atau pinggan ayam yang diisi dengan bara api dan kemenyan, pebayu atau pembantu bomoh dalam ritual pengobatan.

Setelah bomoh selesai membacakan mantra, bomoh menyuruh pembayun untuk membuat tempat permandian. Tempat pemandian tersebut terbuat dari kayu dan dilengkapi dengan sesaji yang 
telah dibacai mantra oleh bomoh. Adapun air dalam permandian tersebut adalah air biasa yang dimasukkan ke empat buah pasu dilengkapi dengan bunga tujuh rupa, antara lain melur, kenduduk, juai, setunduk, lio hutan, bulam. Kemudian air yang telah dicampuri dengan bunga tersebut disirami ke tubuh si sakit. Ini dilakukan empat kali siraman sesuai dengan jumlah pasu atau tempat air.

Selama tiga hari sesudah melakukan pengobatan ini ada beberapa pantangan bagi si sakit dan keluarganya. $\mathrm{Si}$ sakit memiliki pantangan-pantangan yang harus diikuti, yaitu tidak boleh keluar rumah. Hal ini disebabkan oleh si sakit dilarang berada di bawah langit dan di bawah pohon secara langsung. Jika si sakit ingin keluar rumah, maka dia harus memakai payung atau pelindung di atas kepala agar tidak mengenai langit dan pohon secara langsung. Tidak boleh ada barang-barang di rumah pecah atau tidak boleh bersentuhan. Penyakit yang biasa diobati dengan acara ritual ini bermacam-macam, yaitu mulai dari yang ringan seperti sakit perut, demam, sampai pada sakit berat atau parah seperti diguna-guna.

Rangkaian ritual biasanya akan dilakukan dua atau tiga malam berturut-turut. Beberapa larangan harus diikuti oleh keluarga tamu dan bomoh. Daging babi atau kepiting daging lainnya tidak diperbolehkan dibawa masuk ke rumah. Bomoh juga dilarang untuk minum minuman yang mengandung alkohol. Hal ini dilakukan karena dalam ritual yang dilakukan kadang-kadang bomoh akan dibantu oleh roh-roh Melayu yang beragama Islam sehingga untuk dapat melakukan hal tersebut supaya diperlancar jalannya ritual. Hal itulah akan dilakukan tidak memakan daging yang dianggap haram oleh umat Islam, begitu juga minuman yang beralkohol.

Setelah menyelesaikan serangkaian ritual pantangan atau tidak melakukan hal-hal tersebut maka pintu utama tempat ritual tersebut akan ditutup menggunakan daun pandan dari pagi hari sampai dilangsungkan ritual. Penutupan pintu ini bertujuan supaya orang-orang atau tamu yang akan menyaksikan jalannya ritual tidak keluar masuk di area tersebut. Hal inilah yang disebut dengan tabo (tabu) menurut Akit, yaitu daerah pantangan yang harus disterilisasikan dengan orang-orang yang berniat jahat.

Ritual dan prosedur pengobatan yang ada pada suku Akit menyatakan bahwa ritual bedekeh oleh bomoh dijumpai dalam dua sistem. Pertama, sistem penatalaksanaan pengobatan dan kedua sistem perawatan kesehatan. Tahap pertama terdiri atas (a) metode pengobatan yang dilakukan, (b) mencari sebab-sebab terjadinya suatu penyakit (mendiagnosis penyakit), dan (c) penentuan sarana pengobatan. Kedua, sistem perawatan kesehatan meliputi (1) penentuan penyebab penyakit dan (2) tindakan terapi ditekankan pantangan-pantangan yang harus dipatuhi oleh si sakit.

Batin/bomoh adalah orang yang memimpin selama pengobatan ritual ini berlangsung. Pada pelaksanaan awal batin/bomoh akan membaca mantra dengan suara agak keras berupa alunan mantra seperti syair. Pada pelaksanaan awal bomoh membaca bismillah dan bergantung pada roh apa yang akan dipanggil karena bacaan akan diketahui setelah bomoh tersebut waktu kemasukan roh, kadang menyebut nama Allah serta Nabi Muhammad. Ini menunjukkan bahwa nilai-nilai agama juga dibawa pada pengobatan ini. Setelah itu baru bomoh akan membaca mantra dengan suara agak keras alunan mantra seperti syair dengan diiringi bunyi gendang. Bomoh dianggap memiliki kekuatan gaib, yang dapat digunakan untuk tujuan baik dan buruk, mencelakakan lawan, atau menghalau serangan lawan, serta menyembuhkan penyakit, baik yang berasal dari perbuatan manusia maupun karena keteguran ("kemasukan" atau diganggu) roh, hantu, dan kutukan dari roh leluhur dan sebagainya. Dengan kekuatan seorang bomoh dianggap mampu mengatasi gejala-gejala, baik gejala alam yang merugikan manusia maupun dapat menyembuhkan penyakit dengan menggunakan keahlian yang dimilikinya. Bomoh dapat juga dianggap sebagai medium roh, atau kadang-kadang penyembuh, sebagai pemimpin dalam pengobatan, namun bomoh merupakan dukun khusus di suku Akit.

Profesi bomoh secara politis memiliki otoritas wacana kekuasaan. Posisi seorang bomoh menarik berbagai kepentingan sebagai alat legitimasi kekuasaan. Keadaan tersebut juga dimanfaatkan untuk memperoleh kedudukan, penghormatan, dan kekuasaan. Bomoh pada suku Akit dalam pelaksanaan ritual bedekeh mendapatkan tugas dan fungsi masing-masing. Untuk urusan penyakit yang ringan akan diserahkan pada antan atau bomoh kecik dan apabila antan tidak dapat melakukan pengobatan maka akan diserahkan pada bomoh menengah (jakrah). Selanjutnya jika jakrah tidak dapat menyembuhkan pasien, maka batin akan turun langsung memberikan pengobatan. Hal ini merupakan urutan-urutan yang diambil alih oleh batin dalam ritual pengobatan sehingga melibatkan 
unsur-unsur pemimpin dalam masyarakat Akit sebagai satu kesatuan yang mengikat masyarakat tersebut. Diskursus kekuasaan atau pengetahuan bersumber pada pandangan Foucault tentang hubungan antara diskursus (discourse), kekuasaan (power) dan pengetahuan (knowledge). Dalam hal ini bagaimana diskursus mampu menjadi alat berkuasa. Teori wacana menurut Michael Foucault (dalam Ismail, 2002:9), yakni penggunaan kekuasaan untuk membangun kemampuan sebagai manusia yang memiliki pengetahuan untuk melekatkan makna pada pengalaman manusia. Kuasa menurut Foucault tidak dimiliki, tetapi dipraktikkan dalam suatu ruang lingkup stategis yang berkaitan satu dengan yang lain. Michel Foucault meneliti kekuasaan lebih kepada individu. Menurut Michel Foucault, kekuasaan selalu terakulasikan dengan pengetahuan dan pengetahuan selalu memiliki efek kuasa. Dengan kata lain, menurut Foucault, melalui wacanalah yang mendominasi suatu waktu dalam sejarah dan suatu tempat di dunia tertentu.

Foucault (Hoed, 2011: 38) berpendapat bahwa melalui wacana, seseorang, sekelompok orang, atau suatu lembaga dapat merealisasikan kuasa (power). Untuk merealisasikan kuasa tersebut, tidak selalu diperoleh melalui fisik (badaniah atau senjata), tetapi juga melalui pengetahuan yang dimiliki. Foucault (2010) menempatkan kuasa diperoleh dengan menguasai pengetahuan. Dengan kuasa pengetahuan yang dimiliki bomoh yang tersirat dalam ucapan, baik mantra maupun petunjuk yang diucapkannya sebagai pemimpin ritual, merupakan sebuah otoritas kuasa atas komunitas pendukungnya. Kuasa dan pengetahuan merupakan sesuatu yang tidak dapat dipisahkan sebab kuasa menemukan bentuknya dalam pengetahuan. Foucault berpendapat setiap pengetahuan pasti mengandung kuasa dan setiap kekuasaan produktif menghasilkan pengetahuan. Pengetahuan merupakan cara bagaimana kekuasaan memaksakan diri kepada subjek tanpa memberikan kesan ia datang dari subjek tertentu (Haryatmoko, 2003: 225).

Selanjutnya Foucalt juga menyarankan untuk menganalisis kekuasaan sebagai sesuatu yang beredar dan hanya berfungsi dalam bentuk rantai, tidak terlokalisasi di sini atau di sana, di tangan siapa pun, serta tidak pernah disesuaikan sebagai komoditas atau bagian dari kekayaan. Kekuasaan harus dipahami bekerja dan diberlakukan melalui suatu jaring seperti organisasi, tidak hanya seperti individu yang beredar di antara benang; mereka dalam posisi menjalani dan melatih secara bersamaan atas kekuasaan tersebut. Mereka bukan hanya tidak berdaya atau menyetujui sasaran; mereka selalu juga elemen-elemen dari artikulasi. Hal ini mengandung pengertian bahwa "individu-individu adalah merupakan kendaraan kekuasaan, bukan sebatas titik aplikasi”.

\section{SIMPULAN}

Wacana kekuasaan dan pengetahuan digunakan untuk melihat kaitan antara mitologi, silsilah atau sejarah, dan proses ritual bedekeh terkait dengan pengetahuan bomoh mempunyai efek kuasa. Bomoh memproduksi pengetahuan sebagai basis kekuasaan. Pengetahuan berada di dalam relasi-relasi kuasa itu sendiri. Relasi tercipta antara bomoh dan komunitas suku Akit. Tanpa pengetahuannya, bomoh tanpa kuasa. Sebaliknya, tidak ada kuasa tanpa pengetahuan. Produksi pengetahuan yang dilakukan bomoh melandasi kekuasaannya karena setiap kekuasaan disusun, dimapankan, dan diwujudkan lewat pengetahuan. Dalam pelaksanaan bedekeh kedudukan bomoh menghasilkan kebenaran dan pengetahuan tertentu yang menimbulkan efek kuasa. Pengetahuan dan kekuasaan mempunyai hubungan timbal balik.

\section{SARAN}

Profesi bomoh dianggap sangat banyak membantu dan masih sangat dibutuhkan untuk pengobatan. Sehubungan dengan itu, pemerintah diharapkan memberikan bantuan kepada profesi bomoh dari segi pendanaan (tunjangan) agar lebih fokus terhadap profesi sebagai pengobat tradisional. Profesi bomoh tergeser oleh kepentingan pemerintah dengan menerapkan kekuasaan melalui kebijakan undang-undang tanpa memperhatikan kondisi budaya masyarakat yang ada dengan alasan modernisasi dan globalisasi. Ritual bedekeh merupakan salah satu pengobatan alternatif yang harus diakui oleh negara sebagai bagian pengobatan pada zaman modern. Tenaga pengobatan medis diharapkan dapat mendukung peran bomoh melalui praktik pengobatan di permukiman yang jauh dari puskesmas induk sehingga kerja sama yang baik akan menghadirkan keharmonisan dalam masyarakat. 


\section{DAFTAR PUSTAKA}

Erlinda. 2001. Diskursus Estetika Tari Minangkabau di Kota Padang Sumatera Barat Pada era globalisasi. Disertasi. Program Pascasarjana Universitas Udayana Denpasar.

Fakih, Mansour. 1997. Analisis Gender dan Transformasi Sosial (Cetakan Kedua). Yogyakarta: Pustaka Pelajar.

2003. Runtuhnya Teori Pembangunan dan Globalisasi. Yogyakarta: INSIST-Press.

Foster. G.M. \& B.G. Anderson. Antropologi Kesehatan. Jakarta :UI Press 1986.

Foucault, Michel. 2002. Pengetahuan dan Metode Karya-karya Penting Foucault. Yogyakarta: Jalasutra.

1997. Dicipline and Punish: The Birth of the Prison (terjemahan Alan Sheridan). New York: Vintage Books.

2002. Power/knowledge Wacana Kuasa/Pengetahuan (penerjemah Yudi Santosa). Yogyakarta: Benteng Budaya.

Giddens, Anthony. 2003. Masyarakat Post Tradisional. Cetakan Pertama. Diterjemahkan oleh : Ali Noer Zaman. Yogyakarta: IrCisod.

Haryatmoko. 2002. "Kekuasaan Melahirkan AntiKekuasaan, Menelanjangi Mekanisme dan Teknik Kekuasaan Bersama Michael Foucault". BASIS edisi Konfrontasi Foucault dan Marx, No. 01-02, Tahun ke-51, Januari-Februari.
Hoed, Benny H. 2008. "Komunikasi Lisan sebagai Dasar Tradisi Lisan”. Dalam: Pudentia MPPS. (ed). Metodologi Kajian Tradisi Lisan. Jakarta: Yayasan Obor dan ATL. Hal: 183-192.

Hussein, Ismail. 1978. The Study of Traditional Malay Literature with Selected Bibliography. Kuala Lumpur : Dewan Bahasa dan Pustaka.

Lévi-Straus. 1966. The Savage Mind. London: Weidenfold Nicolson.

Lubis, Akhyar Yusuf. 2006. Dekonstruksi Epistimologi Modern, dari Posmodermisme, Teori Kritis, Poskolonialisme Hingga Cultural Studies. Jakarta : Pustaka Indonesia Satu.

Pedoman Kajian Tradisi Lisan. 2012. Pengembangan Kajian Langkah, Kajian Tradisi Lisan sebagai Kekuatan Kultural. Jakarta: Dirjen Dikti.

Sarwono, Solita Wirawan. 1993. Sosiologi Kesehatan. Yogyakarta : Gadjah Mada University Press.

Suroyo. 2017. Ritual Bedekeh Suku Akit di Pulau Rupat Kabupaten Bengkalis Provinsi Riau Pada era Global. Disertasi. Universitas Udayana, Denpasar. 